\title{
Responding to the December 8th Resolution: Of Politics, Free Speech, and Due Process
}

\author{
David W. Louisell* \\ Still thou art blessed, compar'd wi' mel \\ The present only toucheth thee: \\ But ochl I backward cast me e'e, \\ On prospects drearl \\ $A n^{\prime}$ forward, tho' I canna see, \\ $I$ guess and fear. \\ Burns, To a Mouse $\dagger$
}

$\mathrm{R}^{\mathrm{s}}$ Ecollections of December 8, 1964, freshen the meaning of the poet's perception. If men were enough blessed to be touched only by the present, there would be no need and no temptation to summon up remembrance of December 8 th. If men were angels, December 8 th would not have occurred. Because men are what they are, the participants in that day will often return to it. Increasingly, each I think will ask as time broadens perspective and narrows passion: "Would I write and act now as I wrote and acted on December 8th?"

It was perhaps inevitable that this Review would turn to the problems and events of that day. Yet when first approached about this project, I was frankly skeptical about its wisdom and questioned its desirability at a consultative meeting of faculty and editors. Only participants, I thought, could really be knowledgeable enough about that day to be invited to write. Could they at so early a date be scholar enough to justify writing? A commentator on the administration of the late President has reminded us that "an impassioned participant cannot be an objective observer." But the decision for publication was made by our editors largely, perhaps, because of the feeling that if the job were not done now, it would never be done. Thus valuable lessons might be lost. That decision having been taken, I would feel derelict were I to dechine the editors' invitation to write, whatever my doubts as to scholarly perspective-for the viewpoint of the minority in the Academic Senate on December 8th should not pass here unrepresented, liowever relatively small it was on the day of voting. ${ }^{2}$

* B.S.L., 1935, LL.B., 1938, University of Minnesota; Elizabeth Josselyn Boalt Professor of Law, University of California, Berkeley.

t On turning her up in the nest with the plough (reputedly written in the field on the spot); Burns, Poems and Selected Letrers 89, 90 (Hepburn ed. 1959).

1 SORENSEN, KENNEDY 5 (1965).

2 The recorded vote was 824 to 115 . Minutes of the Berkeley Division, Academic Senate, Dec. 8, 1964, p. ii. A much larger minority supported the Feuer amendment. See note 15 infra.

A group of my Berkeley colleagues presented a discussion of the December 8th resolution 
My opinion was and is that the minority was right and that the soundness of its judgment increasingly has been vindicated as events have unfolded since December 8th. Realizing the apparent dogmatism of my thesis, and the limitations from the scholarly viewpoint of one actively engaged who writes so close to the event, I feel that in fairness to the reader I should make clear that my disapproval of the resolution was strong and has remained constant. Accordingly I refer to my remarks in the Academic Senate directed to its problems as I saw them. ${ }^{3}$

The December 8th resolution reads:

In order to end the present crisis, to establish the confidence and trust essential to the restoration of normal University life, and to create a campus environment that encourages students to exercise free and responsible citizenship in the University and in the community at large, the Committee on Academic Freedom of the Berkeley Division of the Academic Senate moves the following propositions:

1. That there shall be no University disciplinary measures against members or organizations of the University community for activities prior to December 8 connected with the current controversy over political speech and activity.

2. That the time, place, and manner of conducting political activity on the campus shall be subject to reasonable regulation to prevent interference with the normal functions of the University; that the regulations now in effect for this purpose shall remain in effect provisionally pending a future report of the Committee on Academic Freedom concerning the minimal regulations necessary.

3. That the content of speech or advocacy should not be restricted by the University. Off-campus student political activities shall not be subject to University regulation. On-campus advocacy or organization of such activities shall be subject only to such limitations as may be imposed under section 2.

4. That future disciplinary measures in the area of political acti-

and connected events at the December 1964 Association of American Law Schools meeting in Chicago. My knowledge of their presentation is only indirect as I was not in attendance. But from conversations with them and others I conclude that their presentations essentially defended the December 8th resolution. In any event, no opponent of the resolution participated. Had I known that the presentation was to take place, I would have felt it important to have been present, that the values of the adversary system might have had a chance to operate. I therefore especially appreciate this chance to state my views to the teaching profession, a number of whom have expressed opinions formulated, in my judgment, on an inadequate knowledge of the events of December 8th.

${ }^{3}$ Minutes of the Berkeley Division, Academic Senate, Jan. 12, 1965, p. ii, reprinted in University Bulletin, University of Califorma, Feb. 1, 1965, pp. 118-19, and Tre BerKeLEY Student Revolt 280-83 (Lipset \& Wolin eds. 1965). At the December 8th meeting itself debate was terminated when a senator successfully moved the previous question. See note 23 infra and accompanying text. On December 10, 1964, I had the opportunity publicly and fully to state my views on the television program, Bay Area Profile, KQED-Channel 9, San Francisco. For that opportunity I am indebted to Dean Newman who made available to the faculty KQED's request for participants. 
vity shall be determined by a committee appointed by and responsible to the Berkeley Division of the Academic Senate.

5. That the Division urge the adoption of the foregoing policies and call on all members of the University community to join with the faculty in its efforts to restore the University to its normal functions. ${ }^{4}$

What was wrong with it? The chief objections I had and still have may be briefly summarized:

First, the resolution reinforced the myth that there was a substantial issue of denial of free speech at Berkeley. The Free Speech Movement (FSM) from September to December 8 th had sedulously and effectively cultivated the myth of denial of free speech, assimilating a free-speech slogan as its name. This tactic was clever, dramatic, and captivating, but I fear that essentially it was sham. Use of the "FSM" slogan was calculated to win instant approbation and to place the opponents of the resolution in the preposterous position of being against free speech. In fact, speech generally was free and fearless among students and teachers. In my time at Berkeley, since 1956, I had never known a colleague or student to feel inhibited in the expression of his views, however unorthodox or "dangerous."

The real issue was not free speech as such but the legitimacy of restrictions on certain activities, principally political and theological ones. Of course the preclusion on campus of certain political activity legitimate off campus in a narrow sense inhibited free speech, to the extent of the relationship of speech to the prohibited conduct. The provision of the Cahifornia constitution, that "the University shall be entirely independent of all political or sectarian influence and kept free therefrom in the appointment of its regents and in the administration of its affairs ..." had on occasions been accorded an exaggerated and unrealistic interpretation productive of unnecessary, undesirable, and ultimately unenforceable restrictions on political and theological activities. ${ }^{6}$ In 1962 a colleague and I critically discussed certain of these restrictions in the pages of this Review. ${ }^{7}$ By fall semester 1964, significant relaxation of the restrictions on pohtical activity on campus had occurred, ${ }^{8}$ although the

4 Minutes of the Berkeley Division, Academic Senate, Dec. 8, 1964, pp. i-ii.

$\sigma$ Cax. Const. art. IX, \& 9.

6 E.g., University Regulation 17, Handbook for Faculty Members of the University of California 41-42, Rev. Sept. 1958; see Louisell \& Jackson, Religion, Theology and Public Higher Education, 50 CALIF. L. REv. 751, 785-89 (1962).

7 Louisell \& Jackson, supra note 6.

8 See, e.g., University of California, Policies Relating to Students and Student Organizations: Introduction, Sept. 1963; Privileges of Student Organizations, July 24, 1961; Use of University Facilities, Rev. Aug. 16, 1961 ; Policy on Off-Campus Speakers, June 21, 1963, all reprinted in the California Monthly, Feb. 1965, pp. 76-79. "The liberalization of faculty and student riglits during the Kerr administration earned for him and the Regents (Spring, 1964) 
rule, restated on September 21, 1964, which forbade students "to urge a specific vote, call for direct social or political action, or to seek to recruit individuals for such action" apparently was not rescinded before November 20,1964. But on November 20,1964, the Regents formally and explicitly repudiated the policy which had prohibited political activity on campus and authorized such activity, provided it would be lawful and not unlawful. On political activity their resolution of that date stated:

The Regents adopt the policy effective immediately that certain campus facilities, carefully selected and properly regulated, may be used by students and staff for planning, implementing or raising funds or recruiting participants for lawful off-campus action, not for unlawful off-campus action. ${ }^{10}$

Thus, whatever free speech issue there had been at Berkeley in respect of political activity, had ceased to exist by December 8 th. The real issue then was whether students could organize and carry on political activities with a guaranteed immunity from University discipline for all such activities, whether lawful or unlawful.

The Senate's resolution, particularly the statement "that the content of speecl or advocacy should not be restricted by the University," in the context of December 8th and the preceding months of disputation, lent support to the myth of general demal of free speech at Berkeley. Indeed, the FSM itself seems to have been more forthright than the faculty, for its pohicy statement had candidly demanded "freedom to advocate off-campus political and social action, ... . to recruit for offcampus political organizations, ... to solicit funds for off-campus political causes."11 Instead of reinforcing the myth of denial of free speech, the Senate should have dehberately and thoughtfully faced up to the real issue, organized student political activity. That would have been a hard task, for however inclined one is to inveigh against extreme interpretations of the California constitutional provision quoted above, it must be admitted that the sharp divorceinent of the University from organized politics had produced an atmosphere of academic freedom from partisan political pressure perhaps unmatched among American public universi-

the American Association of Umiversity Professors' 1964 Alexander Meiklejohn award for conspicuous contributions to academic freedom." Raskin, The Berkeley Affair, N.Y. Times, Feb. 14, 1965, § 6 (Magazine), p. 24, reprinted in The Berkeuex Student Revolt 420, 426 (Lipset \& Wolin eds. 1965). It seems paradoxical that a University so acclaimed for academic freedom in spring, 1964 should be so condemned in fall, 1964.

O Chronology of Events, Three Months of Crisis, The California Monthly, Feb. 1965, p. 57 (event date, Sept. 21, 1964). The Chronology appeared in three issues, those of February, June, and July-August 1965, and hereinafter is cited simply as Chrontology with month of issue and page.

10 Chronology, Feb. 1965, p. 57 (event date, Nov. 20, 1964).

11 Id. at 49 (event date, Oct. 26, 1964). 
ties. That the task of facing up specifically to problems of organized student political activity admittedly would have been a difficult one, is no excuse for the affirmation of the myth of denial of free speech.

Had there been a genuine issue of denial of free speech-had the Regents or any of their agents been in contravention of the first amendment-there was no reason to assume the unavailability of a prompt and effective judicial remedy. Even without submitting to arrest, a test case probably could have been brought as a declaratory judgment action. ${ }^{12}$

Second, the resolution was imprecise. Could the statement, "that the content of speech or advocacy should not be restricted by the University," have seriously been intended to effect precisely what it stated? Was it intended to preclude a foreign langnage professor from proscribing a student's surreptitious reading to his classmates of the English translation of an assigned foreign work, or a mathematics professor from outlawing for his class an answerbook? Was the University always to remain indifferent to whatever words of libel, slander, obscenity, "fighting words, ${ }^{\prime 13}$ or words directed to immediate acts of violence, ${ }^{14}$ that might be spoken or published on the campus? One attempt at clarification, known as the Feuer amendment, would have changed the first sentence of section 3 so that it would have read instead: "That the content of speech or advocacy on this campus, provided it is directed to no immediate act of force or violence, should not be restricted by the University." This was defeated. ${ }^{15}$ Perhaps its defeat could be justified on the ground that it was too narrow a remedy for the broad defects of section 3. I think that in fact it was rejected because of the majority's unwillingness in the excitement of the moment to face up to the hard task of thinking

12 See Walker v. County of Los Angeles, 55 Cal. 2d 626, 361 P.2d 247, 12 Cal. Rptr. 671 (1961); Abbott v. City of Los Angeles, 53 Cal. 2d 674, 349 P.2d 974, 3 Cal. Rptr. 158 (1960). See generally 2 Witkin, California Procedure \$\$ 447-56 (1954, Supp. 1965).

13 E.g., words such as those involved in Beauharnais v. Illinois, 343 U.S. 250 (1952); Chaplinsky v. New Hampshire, 315 U.S. 568 (1941); cf. Terminiello v. Chicago, 337 U.S. 1 (1949).

14 The new University of California Policies Relating to Students and Student Organizations, Use of University Facilities, and Non-Discrimination, which grew out of a report of The Regents' Special Committee to Review University Policies, and promulgated by the President and the Chancellors of all campuses effective July 1, 1965, includes in section II, part A (Standard of Conduct) the provision: "Students shall refrain from conduct which significantly interferes with University teaching, research, administration, or the University's subsidiary responsibilities, or which endangers the health or safety of members of the University community, or of visitors to the campus, and from disorderly conduct on University premises or at University related events." University of California, Policies Relating to Students and Student Organizations, Use of University Facilitics, and Non-Discrimination 5, July 1, 1965.

15 Minutes of the Berkeley Division, Academic Senate, Dec. 8, 1964, p. ii. The vote on this amendment, while not recorded in the Minutes, is given as 737 to 284 in Chronology, Feb. 1965, p. 68 (event date, Dec. 8, 1964). 
and writing precisely in the area of free speech. Yet it seems to me that the duty to try to think precisely and deliberately is directly proportional to the significance of the problem involved. Free speech is too important for careless and hasty definitions. An attempt should have been made to write section 3 so that none but a fool would have invoked it as justification for hard-core affronts to public decency. ${ }^{10}$

Note also the imprecision of section 4 . What do the words, "future disciplinary measures in the area of political activity," mean? Should allegedly obscene conduct be under the jurisdiction of the regular Student Conduct Committee or the committee prescribed by section $4 ?^{17}$ As might have been predicted by a little careful thinking, this became a serious issue in the spring semester. The Acting Chancellor had to resolve it by announcing that "the difficult question of jurisdiction over certain cases of reported obscene conduct" would be settled by creating still another Ad Hoc Committee on Student Conduct. ${ }^{18}$

Third, the resolution was too hastily contrived, considered, and adopted. The Notice of Meeting of the Berkeley Division of the Academic Senate for December 8th, printed under date of December 1, 1964, and distributed, as customary, through the campus mail prior to the noticed meeting, announced a proposed oral report by the Academic Freedom Committee, but nothing further pertinent to the resolution which ensued at the meeting. ${ }^{19}$ Following the oral report, the resolution, which apparently had been prepared at a private meeting of some two hundred faculty member ${ }^{20}$ and was distributed in mimeographed form at the meeting, was presented. Under such exceptional circumstances the

16 A partial history of the "Filthy Speech" Movement appears in Chronology, June 1965, pp. 53-56 (event dates, March 3, 4, 5, 9, 10, 11, 12, 13, 16, 18, 19, 22, 23, 24, 26, 31, April $2,6,20,21,22,23,25,1964)$. Further comment is here withheld because the writer is informed that phases of the controversy are still sub judice.

17 Section 4 provides: "That future disciplinary measures in the area of political activity shall be determined by a committee appointed by and responsible to the Berkelcy Division of the Academic Senate." A Faculty Judicial Committee on Pohtical Activity was appointed by the Acting Chancellor. University Bulletin, University of Cahfornia, Feb. 23, 1965, p. 131. But no committce for disciplinary measures in the area of political activity "appointed by and responsible to the Berkeley Division of the Academic Senate" ever came into being. Perhaps this is commentary enough on the deficiencies of section 4.

18 Chronology, June 1965, p. 53 (event date, March 11, 1965). The membership of this additional committee was drawn: two from the regular Student Conduct Committee, two from the Faculty Judicial Committee on Political Activity, with a chairman from the Academic Senate who was not a member of either committce.

19 Notice of Meeting of the Berkeley Division, Academic Senate 1, Dec. 8, 1964.

20 Chronology, Feb. 1965, p. 68 (event date, Dec. 8, 1964). So far as known to the writer, there is no recorded account of the actual circumstances and conditions under which the December 8th resolution was written. An accurate history in this regard would doubtless he a valuable document in the service of truth. 
Senate, with approximately 1,021 voting members present, ${ }^{21}$ proceeded to debate one of the most serious problems that ever confronted it.

After about an hour and a half's debate on the resolution itself, with about equal time for the aforementioned Feuer amendment, ${ }^{22}$ further debate was foreclosed when a senator successfully made a motion for the previous question. ${ }^{23}$ The purport and significance of this parliamentary technique did not appear to be generally understood, and it required a ruling from the parliamentarian. Thereafter, the resolution passed by the recorded vote of 824 to $115 .{ }^{24}$ "Nearly three thousand observers, gathered outside Wheeler Hall (where the meeting was in progress), listened to the proceedings over loudspeakers. They cheered as the vote defeating Feuer's amendment was announced; they wildly cheered the announcement of the main motion's final passage."25

The Regents "did not accept" the Senate's "proposed solution to the 'free speech' controversy." They did, however, "reaffirm devotion to the First and Fouteenth Amendments" and provide that their policies "do not contemplate that advocacy or content of speecli shall be restricted beyond the purview" of those amendments. ${ }^{28}$

In my opinion neither the hour nor the circumstances were appropriate for a university faculty resolution that purported to declare authoritatively on free speech. There are times when parliamentary proceedings require deliberate orderliness as much as judicial proceedings, lest the passionate elements of human nature preponderate over the intellectual. If it be objected that the hour was desperate and the crisis overwhelming, I can only reply that desperate hours and overwhelming crises define the true meaning of due process in judicial proceedings. ${ }^{27}$ And if I may be pardoned a personal reference, my experiences as counsel for the accused before the McCarthy Committee tend to substantiate the opinion that the need for and the values of due process are not himited to judicial proceedings. ${ }^{28}$

21 Minutes of the Berkeley Division, Academic Senate, Dec. 8, 1964, p. i.

22 Chronology, Feb. 1965, p. 68 (event date, Dec. 8, 1964).

23 "The purpose of the motion for the previous question is to close debate peremptorily and bring the assembly to an immediate vote on the pending question. . . . It precludes both debate and amendment and requires a majority vote only for passage." 17 Encyctopedia BrTtannica 327 (1948); cf. Robert, Rules of Order Revised § 29 (1915) which states that the motion requires a two-thirds vote for adoption. There is no doubt that its object is to bring the assembly at once to a vote, and its effect, when adopted, is to close debate immediately.

24 Mimutes of the Berkeley Division, Academic Senate, Dec. 8, 1964, p. ii.

25 Chronology, Feb. 1965, p. 68 (event date, Dec. 8, 1964).

28 Id. at 73 (event date, Dec. 18, 1964).

27 See, e.g., De Meerleer v. Michigan, 329 U.S. 663 (1947); Moore v. Dempsey, 261 U.S. 86 (1923); cf. Estes v. State of Texas, 381 U.S. 532 (1965).

28 One of my lady colleagues, seeking to leave the hall as promptly as possible after 
Fourth, the resolution tended to undermine the University's autonomy. Whatever the failures and deficiencies of this University, it seems to me that judged over the long pull it has sustained to a remarkable degree the values of academic freedom against the ever-lurking potential of partisan political interference that not infrequently has jeopardized other state universities. I think that our relative success is attributable in part to our constitutional plan which aims at an essentially independent Regency..$^{29}$ Americans historically are accustomed to the realities of a tripartite system of government, and to the indispensable play in the joints that makes sucli a system viable: A strong Presidency may tend to dominate Congress; a strong Congress may attempt something of a de facto receivership for a weak Presidency; an independent judiciary struggles to hold this, and the other governmental balances, true. When as with us Californians, an almost fourth branch, the constitutionally chartered University, is an integral part of the governmental structure, the problems of balance, of oiling the machinery, of mutual restraint and regard, of action when needed and abstinence when prudent, are of increased complexity and enhanced delicacy. No talismanic formula can demark the limits of University autonomy or of the Legislature's impinging potentials by reason of its liold on the purse strings. Ultimately the appeal is to the spirit of reasonableness in the light of the purpose of academic freedom.

Did the Senate tend to lold the balance true when under the circumstances noted it wrote in section 3: "Off-campus student political activities shall not be subject to University regulation"? There is no gainsaying the difficulty of the problem with which that sentence attempts to deal. Since December 8th it has been the subject of recurring study; the best that yet has been done about it is the provision in the new state-wide policies that "a student nuay not be disciplined for off-campus conduct unless such conduct affects his suitability as a student."30

Of course, during the years when the University attempted to preclude organized student political activity on campus, it was perhaps reasonable

adjournment on December 8th, was reproved by a bystander who told her she was supposed to walk down a lane reserved so that emerging senators could receive "the applause of the crowd." It is not pleasant to contemplate what might have ensued had the bystander not given way to her insistence that she would walk where she wished, forcibly if necessary.

29 The Regents of the University of California include eight ex officio members (Governor, Lieutenant Governor, Speaker of the Assembly, Superintendent of Public Instruction, President of the State Board of Agriculture, President of the Mecharics Institute of San Francisco, President of the Alumni Association, and President of the University) and sixteen appointive members appointed by the Governor for terms of sixteen years. Cax. Const. art. IX, \& 9.

30 University of California, Policies Relating to Students and Student Organizations, Use of Facilitics, and Non-Discrimination 8, July 1, 1965 (Part E., Student Discipline, b.2). 
for it to disclaim concern with what students did politically off campus. For then it was plausible to assume that the off-campus political conduct was disassociated from the campus, was performed by students solely in their capacities as citizens, and lience was not within a state university's legitimate domain. But when, as the December 8th resolution contemplates, students were to be given carte blanclie for on-campus organized political activity, would it be proper for the University at the same time to forego all concern with off-campus conduct arranged on campus? On the one hand, wholesale abandonment by the University of all concern with student conduct planned, originated, and essentitally carried on from the University base with use of University facilities, just because the conduct is effected off campus, would seem to invite an interference by civil authorities which might be withheld were the University to exercise its disciplinary jurisdiction, in accordance with the historic American university practice. On the other hand, over the long pull the University, besides comporting with due process, might well provide a more truly understanding and potentially rehabilitative tribunal for the student, than the criminal law's procedures. As to on-campus conduct, total abandonment of all University concern save as to formalities of time, place, and manner could well invite decrease in autonomy by precipitating or arguably justifying outside forays onto the campus.

Admittedly the problems of the proper relations of University to students are of increasing conplexity in modern society. Students generally are more knowledgeable, highly travelled, experienced, and independent, and many of them are more firmly committed politically and ideologically, than ever before. Disciplinary objectives reasonable even twenty years ago may be preposterous today. What should have been apparent on December 8th was that the University's concern with organized student political conduct was not susceptible of adequate treatment by hasty declarations in an emotion-frauglit atmosphere, not even by a body as experienced as the Senate. For a wise consideration could not evade careful attention to the problem of student discipline in the context of our historic autonomy. As I attempted to express it:

[T] here does seem to be a serious problem as to whether the University should wholly abandon its disciplinary jurisdiction just because a student's conduct is also within the jurisdiction of the criminal courts. I think two different kinds of conduct should be clearly distinguished. First, suppose that students organize on this campus a sit-in or other activities to be carried on in a state whose regulations are themselves illegal because in contravention of paramount federal law. Such student conduct may be not only morally commendable but perfectly legal; it may in fact be in vindication of the federal law as the supreme law of the land. 
Next, suppose that students organize on campus a sit-in or other activities off campus in California and carry them on under circumstances and in a manner that is clearly and palpably illegal. It can be argued that this should be left solely to criminal prosecution. Perhaps normally it should, as a matter of prudent judgment, just as other crimes, for example, homicides committed on campus, would be left to criminal prosecution. Even so, I doubt that one would seriously question the Umversity's possible interest in suspending dangerous students during the legal proceedings if the facts indicated that necessity.

It should be remembered that the court proceedings in politically motivated offenses might well take two years or more, especially if review by the United States Supreme Court were sought. In the meantime the defendants, presumably on bail, would have the capacity to repeat the offense. I doubt that many would contend that the University should be wholly indifferent to such student conduct just because criminal proceedings were pending, particularly if the conduct were especially outrageous. It must be remembered that characterizing conduct as "political" or "politically motivated" does not diminish its criminality if in fact it is criminal.

The same kind of problem could arise respecting conduct on campus. Suppose a student commits a violent assault on, or murder of, a fellow student or professor. He is acquitted of the crininal charge on the ground of insanity at the time of the offense, and discharged from custody on the ground that he is now competent. Should the Umiversity be wholly foreclosed from appraisal of his readmissibility?

These may be hard questions, especially when posed out of the context of the full facts of an actual case. We should be careful not wholly to give up all potential jurisdiction on abstract grounds lest we make wise handling of future cases difficult or impossible. I fear that such blanket abdication of responsibility historically assumed by universities will tend to undermine our autonomy by inviting increased intervention of the civil authorities. ${ }^{31}$

31 Minutes of the Berkeley Division, Academic Senate, Jan. 12, 1965, p. ii, reprinted in University Bulletin, University of California, Feb. 1, 1965, pp. 118-19, and THE BERKELEY REvolt 281-82 (Lipset \& Wohin eds. 1965). More recently Burke Marshall, formerly Assistant Attorney General for the Civil Rights Division, Departneent of Justice, has stated the importance of the distinction between legal and illegal conduct, from the viewpoint of the protest movement, in these words: "The fact is that the protest program actually put into effect in Alabama involved nothing that was illegal in an ultimate sense. True, the participants expected that they would be arrested, and that some would go to jail. But they expected this not because they intended to break any constitutional laws. They acted at all times with careful legal advice, under a claim of right under the federal constitution to do what they did, whatever legal steps might be taken in retaliation by state or local law enforcement officials.

"What disobedience was involved, therefore, was not to the law in general, but only to local law which they could reasonably suppose, and $I$ am sure did in fact suppose, to be unconstitutional. In the language of the theory of civil disobedience, it would accordingly be accurate to replace the adjective "unjust" with "unconstitutional" in describing laws that could not in conscience be obeyed. To put it another way, the action taken by the members of the protest movement merely asserted legal rights gunranteed by the federal constitution, 
In any event, solution of the problem could hardly be aided by the hasty and I fear dogmatic treatment of December 8th. The faculty owed more than it gave to the principle of University autonomy. But there is reason to hope that they will be remembered not for the excited utterance of a moment, but for the pattern of their fealty to a chief prop of academic freedom, University independence. December 8th was an aberration, not the norm. It need no more destroy our University's independence than the House's preposterous impeachment of President Andrew Johnson destroyed the American constitutional plan of checks and balances.

Fifth, the resolution represents a lost opportunity. Putting aside the relatively few students who seem to have been devoted to disorder for disorder's sake, I think that most in that crowd outside Wheeler Hall on December 8th were as intelligent, idealistic, and unselfish as any students that have ever graced any campus. There was a golden chance to teach them the lofty teaching of the ancient wisdom: He that rules his own spirit is greater than he that rules a nation. They might have been told: "We will always reason with you, that the purposes of the first amendment may ever be more perfectly fulfilled. But as University spokesmen we will never capitulate to a tantrum. We will therefore adjourn until reason can have its hearing in this, its truest home, a university."

It is sad that in that hour their teachers failed them. They failed to display that devotion to reason and its methods which one hikes to think is customary for American universities. But it may be hoped that the students will remember those teachers not for the failure of a moment, but for the struggles of a lifetime. And perhaps many of those teachers, being devoted to the pursuit of the truth, with candor equal to their zeal on December 8th may yet say of that day, to themselves if not to the world-for not even teachers are angels-the poet's noble mea culpa:

The thorns which I have reap'd are of the tree

I planted: they have torn me, and I bleed:

I should have known what fruit would spring from such a seed. ${ }^{32}$

but denied to them by unconstitutional, and therefore unlawful, local police action." Marshall, The Protest Movement and the Law, 51 VA. L. Rev. 785, 795 (1965).

32 Byron, ChILde Harold's Pugrimage 187 (Darmesteter ed. 1882) (Canto IV, X). 